\title{
Complement as a regulator of adaptive immunity
}

\author{
Justin Killick $^{1}$ - Gregoire Morisse ${ }^{1,2} \cdot$ Dirk Sieger $^{2} \cdot$ Anne L. Astier $^{1,3}$ (D)
}

Received: 17 May 2017 / Accepted: 3 August 2017 /Published online: 25 August 2017

(C) The Author(s) 2017. This article is an open access publication

\begin{abstract}
The complement system is an ancient and evolutionarily conserved effector system comprising in mammals over 50 circulating and membrane bound proteins. Complement has long been described as belonging to the innate immune system; however, a number of recent studies have demonstrated its key role in the modulation of the adaptive immune response. This review does not set out to be an exhaustive list of the numerous interactions of the many complement components with adaptive immunity; rather, we will focus more precisely on the role of some complement molecules in the regulation of antigen presenting cells, as well as on their direct effect on the activation of the core adaptive immune cells, B and T lymphocytes. Recent reports on the local production and activation of complement proteins also suggest a major role in the control of effector responses. The crucial role of complement in adaptive immunity is further highlighted by several examples of dysregulation of these pathways in human diseases.
\end{abstract}

Keywords Complement $\cdot$ Adaptive immunity $\cdot$ T cells $\cdot$ B cells $\cdot$ CD46 $\cdot$ Inflammation

This article is a contribution to the special issue on Complement in Health and Disease: Novel Aspects and Insights - Guest Editors: Paul Morgan and David Kavanagh

Anne L. Astier

anne.astier@inserm.fr

1 MRC Centre for Inflammation Research, Edinburgh Centre for MS Research, University of Edinburgh, Queen's Medical Research Institute, Edinburgh EH16 4TJ, UK

2 Centre for NeuroRegeneration, Edinburgh Centre for MS Research, University of Edinburgh, Edinburgh EH16 4SB, UK

3 Inserm U1043, CNRS U5282, Université de Toulouse, Centre de Physiopathologie Toulouse-Purpan (CPTP),

F-31300 Toulouse, France

\section{Introduction}

For many years, the complement system has been described as being a key element in innate immunity. This ancient evolutionary system is indeed crucial to fight pathogens, by patrolling as sentinels in the circulation and targeting these invaders for destruction, as well as initiating inflammatory responses [1]. In the past decade, it has become clear that components of the complement system also represent an integral part of the regulation of the adaptive immune response. Indeed, complement components and their receptors are expressed and produced by adaptive immune cells. The interaction of complement proteins and their cognate receptors has been shown to control several functions ranging from activation, differentiation, and metabolism of adaptive immune cells [2]. The recent discovery that complement is not only present in serum and other fluids but also has been shown to be activated intracellularly, including in lymphocytes, opens novel doors on the role of the complex interactions between this innate system and the control of adaptive immune responses [3]. This review will present recent advances in this field, with a particular focus on the regulation of $\mathrm{B}$ and $\mathrm{T}$ cell activation by complement components, and how dysregulation of these controls can lead to pathogenesis.

\section{Adaptive immunity}

Immune responses have traditionally been grouped into either innate or adaptive responses. The innate response is fast but non-specific. The complement system is one of the first parts of the innate response to be activated when "foreigners" such as bacteria invade the body, and it presents an immediate and critical tool to help defend against infections and clear pathogens by allowing their opsonization and further killing [1]. Adaptive immunity on the other hand, although slower, elicits a very specific immune response through the activation of 
immune cells ( $\mathrm{T}$ cells and B cells) that express highly specific antigen receptors. The adaptive immune response is also able to develop a memory to the antigen, allowing a faster and stronger response upon re-encounter. In recent years, a finely tuned interplay between these two types of immune response has been reported and is now extensively studied. Notably, the complement system has been shown to directly control B and $\mathrm{T}$ cell responses $[2,4]$.

Naïve T cells are activated by their cognate TCR following the recognition of a specific peptide from a given antigen presented by the MHC, hence conferring the specificity of the $\mathrm{T}$ cell response. Full activation, however, requires co-stimulation and is provided by the engagement of co-stimulatory molecules expressed on T cells and ligated by their cognate receptors at the surface of antigen presenting cells (APC) [5]. Depending on the cytokines and signals received by the naïve $T$ cells, these will differentiate within different $\mathrm{T}$ helper $(\mathrm{Th})$ subsets [6]. These differentiated Th subsets are, however, not static as they exhibit a certain level of plasticity and are able to modulate their cytokine profiles depending on the surrounding environment and the signals received. In counterpoint to these effector Th subsets, a variety of regulatory $\mathrm{T}$ cells (Tregs) operate, essential to control immune homeostasis by counteracting overactivation of effector T cells [7]. Lack of regulatory T cells or dysfunction of these cells is indeed detrimental to health, giving rise to allergy or autoimmune diseases.

Similarly, B cells are adaptive immune cells that are specific to a given antigen. As opposed to T cells, B cells recognize the whole antigen and not a processed peptide. Recognition of the antigen is made by the unique $\mathrm{B}$ cell receptor (BCR) expressed at the cell surface, namely a membrane-bound immunoglobulin. Full activation of B cells also requires co-stimulation alongside BCR stimulation, such as ligation of the cell surface molecule CD40. Recent studies have highlighted the existence of specific regulatory $\mathrm{B}$ cells (Bregs) that also contribute to the maintenance of immune homeostasis in a manner analogous to Tregs [8].

\section{Complement components and their receptors and regulators modulating adaptive immunity}

This review does not expand on the different complement activation pathways and cascades leading to the formation of membrane attack complexes (MAC) as this is covered in depth in other reviews in this issue. We will, however, briefly describe some of the complement receptors and complement regulators that are involved in the regulation of the adaptive immune cells, as further discussed below.

Complement activation results in the generation of $\mathrm{C} 3$ and $\mathrm{C} 5$ convertase complexes; these will cleave $\mathrm{C} 3$ and $\mathrm{C} 5$, respectively, generating the anaphylatoxin components $\mathrm{C} 3 \mathrm{a}$ and $\mathrm{C} 5 \mathrm{a}$ as well as the opsonin $\mathrm{C} 3 \mathrm{~b}$ and $\mathrm{MAC}$ initiator $\mathrm{C} 5 \mathrm{~b}$. Binding of $\mathrm{C} 3$ and $\mathrm{C} 5$ fragments to their cognate receptors/ regulators triggers intracellular signaling resulting in the modulation of key cellular functions.

\section{Complement receptors}

CD21, also called complement receptor 2 (CR2), is a cell surface glycoprotein which binds and recognizes a variety of ligands, such as the Epstein-Barr virus, the IgE receptor $\mathrm{CD} 23$, IFN $\alpha$, and the complement $\mathrm{C} 3$ degradation products $\mathrm{C} 3 \mathrm{~d}$, iC3b, and C3d,g. CD21 profoundly modulates B cell functions, as further discussed below.

Complement C3a receptor, C3aR, is a G-protein-coupled receptor (GPCR) which interacts with complement component $\mathrm{C} 3 \mathrm{a}$. C3aR has been shown to be present on both $\mathrm{B}$ cells and $\mathrm{T}$ cells; however, much of the literature has focused on its role in modulating T cell-mediated immunity [9]. In resting T cells, C3aR is only expressed intracellularly within lysosomes, while upon activation, the receptor is translocated to the plasma membrane [3].

Complement C5a receptor 1, C5aR1 (CD88), is a GPCR which binds to the complement components $\mathrm{C} 5 \mathrm{a}$ and desarginated $\mathrm{C} 5 \mathrm{a}\left(\mathrm{C} 5 \mathrm{a}^{\text {desArg }}\right)$. Although initially suggested that C5 $\mathrm{a}^{\text {desArg }}$ bound to C5aR1 with less affinity than C5a [10], this was recently challenged [11]. Its localization appears to be somewhat dependent on cell type, as it is detected both in the cytoplasm and on cell membrane in monocytes whereas it appears to be exclusively localized within the cell in T cells $[12,13]$. C5aR1 is present on a variety of cell types, not exclusively immune cells. Its interaction with $\mathrm{C} 5 \mathrm{a}$ is believed to be pro-inflammatory and contributes to the pathogenesis of several inflammatory diseases.

C5aR2 (or C5L2) binds to both C5a and C5 $\mathrm{a}^{\text {desArg }}$ with comparable affinity to C5aR1. C5aR2 is a seven-transmembrane domain receptor, localized primarily intracellularly but also expressed on the cell membrane [12]. C5aR2 shares 38\% sequence homology with the $\mathrm{C} 5 \mathrm{aR} 1$ receptor but does not couple to G proteins [14]. The lack of GPCR-coupled signaling led to the belief that this receptor was a "decoy" receptor with no other function than to compete for C5a binding with C5aR1 [15]. However, recent studies have shown that $\mathrm{C} 5 \mathrm{aR} 2$ can recruit and signal through $\beta$-arrestin, having both pro- and antiinflammatory effects depending on the cell type and signaling conditions [13].

\section{Complement regulators}

CD46, also known as membrane co-factor protein (MCP), is a member of the regulators of complement activation (RCA) family. CD46 is ubiquitously expressed (except for erythrocytes) and, along with other complement regulators, protects cells from autologous complement mediated lysis, by binding to complement components $\mathrm{C} 3 \mathrm{~b}$ and $\mathrm{C} 4 \mathrm{~b}$ and facilitating their degradation by factor I. CD46 also acts as a receptor for 
several pathogens including measles and adenoviruses and the Neisseria (N) gonorrhoeae and $N$ meningitides bacteria [16]. In addition, CD46 is a powerful regulator of T cell-mediated immunity, as further discussed below.

CD55, also known as decay accelerating factor (DAF), is a glycosylphosphatidylinositol (GPI)-anchored cell surface molecule, and a member of the RCA family. CD55 promotes the degradation and inhibits the formation of complement $\mathrm{C} 3$ and $\mathrm{C} 5$ convertases and thus prevents amplification of the complement cascade and formation of the MAC.

CD59, another GPI-anchored molecule, prevents complement-mediated lysis of autologous cells by inhibiting the interaction between complement $\mathrm{C} 9$ and $\mathrm{C} 5 \mathrm{~b}-8$ complex, hence preventing the formation of the MAC [17].

CD35, or complement receptor 1 (CR1), is a transmembrane glycoprotein and a member of the RCA family. CD35 binds the ligands $\mathrm{C} 3 \mathrm{~b}$, iC3b, and $\mathrm{C} 4 \mathrm{~b}$. Like CD55, CD35 has decay accelerating activity promoting the degradation of complement $\mathrm{C} 3$ and $\mathrm{C} 5$ convertases. However, unlike other members of the RCA family, CD35 possesses both decay accelerating activity and cofactor activity for factor I-mediated complement cleavage. CD35 catalyzes factor I cleavage of $\mathrm{iC} 3 \mathrm{~b}$ to $\mathrm{C} 3 \mathrm{c}$ and C3dg, the latter being a ligand for CD21 [18].

$\mathrm{C} 4 \mathrm{~b}$ binding protein $(\mathrm{C} 4 \mathrm{BP})$ is a multimeric serum soluble glycoprotein produced and secreted primarily by the liver. Several isoforms of C4BP exist, composed of various combinations of alpha and beta chains. C4BP has both decay accelerating activity and cofactor activity for factor I-mediated cleavage, resulting in the dissociation of $\mathrm{C} 3$ convertases and degradation of $\mathrm{C} 3 \mathrm{~b}$ and $\mathrm{C} 4 \mathrm{~b}$, respectively. Serum localized C4BP forms a complex with vitamin-K-dependent protein $\mathrm{S}$, which allows binding to negatively charged phospholipids such as the apoptotic cell marker phosphatidylserine [19]. The binding of C4BP to apoptotic cells inhibits complement $\mathrm{C} 3$ and $\mathrm{C} 5$ convertase formation and subsequent lysis by MAC formation, preventing the induction of an inflammatory response due to excessive complement activation and the release of cellular contents due to cell lysis [20].

Factor $\mathrm{H}(\mathrm{FH})$ is a soluble complement regulator present in the plasma [21]. It binds and inhibits $\mathrm{C} 3 \mathrm{~b}$. Factor $\mathrm{H}$ acts as a co-factor for factor I-mediated cleavage of complement component $\mathrm{C} 3 \mathrm{~b}$ to $\mathrm{iC} 3 \mathrm{~b}$, preventing the assembly of the $\mathrm{C} 3 \mathrm{bBb}$ alternative pathway $\mathrm{C} 3$ convertase. Factor $\mathrm{H}$ can also facilitate the decay of already formed $\mathrm{C} 3 \mathrm{bBb} \mathrm{C} 3$-convertase by displacing bound $\mathrm{Bb}$ from $\mathrm{C} 3 \mathrm{~b}$.

\section{Complement in APC function}

One of the primary functions of the innate immune system is the recognition, uptake, and presentation of foreign pathogens to activate the adaptive immune system. Upon recognition of an antigen by APC, such as dendritic cells (DCs), the entity is engulfed, digested, and the subsequent antigenic peptide is presented on MHC receptors at the APC surface to activate the specific $\mathrm{T}$ cells. The serum complement system forms an integral part of this process through the opsonization of foreign entities, which improves antigen recognition and uptake into APCs via complement receptors CD21 and CD35 [22]. DCs, along with macrophages and mast cells, are one of the largest producers of extra-hepatic $\mathrm{C} 1 \mathrm{q}$ which induces cellular responses on local tissues in a paracrine manner [23]. C1q induces maturation of DCs and upregulates expression of cell surface MHC class II and CCR7, the latter being a chemokine receptor necessary for DC migration towards the lymphoid tissue [24]. C1q-matured DCs also secreted higher amounts of IL-12p70 which in turn stimulates a greater Th1 response from co-cultured T cells [24]. However, C1q bound to apoptotic cells induced DCs to secrete IL-10 as opposed to IL-12p70, suppressing Th1 and Th17 cell proliferation [25]. DC production of $\mathrm{Clq}$ ceases upon maturation, which may represent a negative feedback loop, limiting DC maturation; it may also serve to restrict $\mathrm{C} 1 \mathrm{q}$ production in lymphoid tissues where it could have a direct impact on $\mathrm{B}$ and $\mathrm{T}$ cell responses [23].

In a model of influenza infection, $\mathrm{C} 3$ is required for the migration of lung DCs to the lymph nodes [26]. CD46 ligation by measles virus or antibodies on human DCs has been reported to modulate secretion of the pro-inflammatory cytokines IL-12 and/or IL-23 [27-29]. Hence, complement modulates the ability of DCs to migrate towards the lymphoid tissue and modulates the adaptive response through regulation of cytokine secretion. Local production of $\mathrm{C} 3 \mathrm{a}$ and $\mathrm{C} 5 \mathrm{a}$ at the APC-T cell interface is also key to regulate $\mathrm{T}$ cell activation and survival [30]. Exogenous FH also modulates the maturation and function of DCs and their ability to stimulate T cells. Treatment of monocyte-derived DC (MoDC) with FH prior to LPS stimulation resulted in the generation of a phenotypically immature MoDC population. These cells displayed reduced antigen uptake, CCR7 expression, and chemotactic ability. When co-cultured with $\mathrm{CD} 3+\mathrm{T}$ cells, they induced a $\mathrm{CD} 4{ }^{+} \mathrm{CD} 127^{\text {low }} \mathrm{CD} 25^{\text {high }} \mathrm{Foxp} 3^{+}$regulatory $\mathrm{T}$ cell population [31]. In concordance with these observations, it was shown that IFN $\gamma$-activated DCs resulted in increased expression of cell surface factor $\mathrm{H}$. Inhibition of factor $\mathrm{H}$ expression resulted in increased $\mathrm{CD} 4+\mathrm{T}$ cell activation and proliferation. These findings suggest a role for factor $\mathrm{H}$ in the regulation of $\mathrm{DC}$ function and its modulation of $\mathrm{T}$ cell responses [32].

\section{Role of complement in B cell regulation}

Complement plays a modulatory role in a variety of B cell functions, including activation and differentiation, antigen internalization and presentation, and immunoglobulin class switching. The importance of these interactions is highlighted by the variety of diseases that can occur when the complement system becomes dysregulated. 


\section{$B$ cell activation}

Naive B cells require two activation signals to become optimally activated, begin proliferating and generating antigen specific antibodies. The first activation signal is propagated through the stimulation of the BCR and its co-receptor complex composed of complement receptor 2 (CR2, CD21)/CD19/ CD81 [33]. The second activation signal typically involves CD40 on B cells and its cognate ligand on T cells, CD154 (CD40L) [34]. Co-engagement of the BCR and of CD21 by $\mathrm{C} 3 \mathrm{~d}$-opsoninized antigen enhances $\mathrm{B}$ cell activation $[4,35]$, by reducing the amount of antigen required for activation by between two- and four-fold; thus, C3d has been described as an antigen adjuvant. Co-engagement of the BCR and CD21/CR2 is also key to the generation of B cell memory [4].

$\mathrm{B}$ cell surface complement receptor 1 (CD35, CR1) binds to the complement components $\mathrm{C} 3 \mathrm{~b}$ and $\mathrm{C} 4 \mathrm{~b}$, acting as a cofactor to facilitate their cleavage by factor I to $\mathrm{iC} 3 \mathrm{~b}$, a substrate for CD21, and $\mathrm{iC4b}$, respectively [36]. While CD21, as mentioned previously, promotes $\mathrm{B}$ cell activation, CD35 has an antagonistic effect, suppressing $B$ cell activation and proliferation [37].

\section{Antigen internalization and presentation}

The interaction of C3 fragments with CD21 plays a fundamental role in B cell antigen internalization and presentation [38]. Internalized antigen is processed and the peptide presented on surface MHC-Cl.II receptors to activate local T cell responses [39]. Brimnes et al. [40] observed that B cells incubated in either serum-free media or with heat or chemically inactivated complement showed significantly reduced ability to uptake antigen. Blockage of CD21 with polyclonal antibodies also significantly reduced antigen uptake and presentation. The B cell uptake of complement $\mathrm{C} 3 \mathrm{~d}$-coated antigen plays an important role in formation and maintenance of germinal centers and the subsequent differentiation of memory and effector B cells. $\mathrm{B}$ cells are observed to transfer complement-coated antigen to follicular DCs via the CR2 receptor; these store the antigen, periodically transferring it back to the $\mathrm{B}$ cells to maintain the germinal centers and extend the humoral response [22, 41].

\section{Immunoglobulin class switching}

The complement receptor $\mathrm{CD} 21$ and the complement regulators CD46 and C4BP modulate B cell immunoglobulin class switching, particularly IgE switching. Resting B cells typically express the IgM or IgD immunoglobulin isotypes. Upon differentiation, B cells switch their class immunoglobulins depending on surrounding cytokines and interaction with cell surface receptors such CD40 and the IgE receptor CD23. The earliest indication of the involvement of CD21 in IgE class switching was the discovery of its ability to bind to CD23
[42]. CD21 bound to either soluble CD23, Epstein-Barr virus fragments or monoclonal antibodies in the presence of the stimulatory signals IL-4 and anti-CD40, results in an increased production of mature IgE mRNA and secreted $\operatorname{IgE}$ $[42,43]$. Geha's group reported that the complement regulator C4BP binds to B cell surface CD40 inducing B cell activation and proliferation, and, in the presence of IL-4, also induces immunoglobulin class switching to promote the secretion of IgE [44]. Although CD46 stimulation has been observed to increase IgE germline transcripts, this does not result in increased secretion of IgE [45]. Moreover, co-ligation of CD46 with CD40 on B cells inhibits IgE class switching through blockage of CD40-mediated NFKB activation. Hence, a variety of complement components can differentially modulate IgE secretion depending on the target receptors involved. A summary of the roles of complement in antigen presentation and B cell function is depicted in Fig. 1.

\section{Role of complement in $\mathrm{T}$ cell activation}

A growing body of evidence suggests that several members of the complement family interact with CD4+ T cells through interaction with cell surface and intracellular receptors modulating activation and subset differentiation.

\section{T cell activation and differentiation}

Activation by CD46 has been shown to profoundly affect T cell activation. Co-stimulation by CD3/CD46 transduces signals resulting in a strong proliferative response of activated $\mathrm{T}$ cells [46-48], and differentiation into Th1 cells characterized by IFN $\gamma$ production [49]. As IL-2 accumulates in the surroundings of the cells, a contraction phase occurs, with decreased IFN $\gamma$ production but enhanced secretion of IL-10. The release of high levels of IL-10 and low IFN $\gamma$ leads to suppression of proliferation of bystander T cells; hence, CD46-costimulated T cells acquire a phenotype of so-called type I regulatory T cells $(\operatorname{Tr} 1)$ [50]. CD46 co-stimulation modulates expression of Notch family members at the surface of activated T cells, while on resting T cells, CD46 binds to the Notch family member Jagged1, inhibiting both Notch signaling and CD46 activation. Activation of CD46 leads to CD46 downregulation, freeing Jagged 1 to interact with Notch [51]. Interestingly, Notch regulates IL-10 secretion in Th1 cells [52]. Hence, CD46 may provide the link between the Notch and complement cascades to regulate $\mathrm{T}$ cell differentiation and IL-10 production.

Enzymatic processing of CD46 occurs upon T cell activation, leading to the shedding of its extracellular domain and subsequent cleavage of its two cytoplasmic tails, Cyt1 and Cyt2. The two tails exhibit antagonistic roles in the control of inflammation, in both huCD46-transgenic mice (mice only express CD46 on testis) [53] and in human T cells in vitro [54, 55]. Processing of CD46 is required for IL-10 production and 


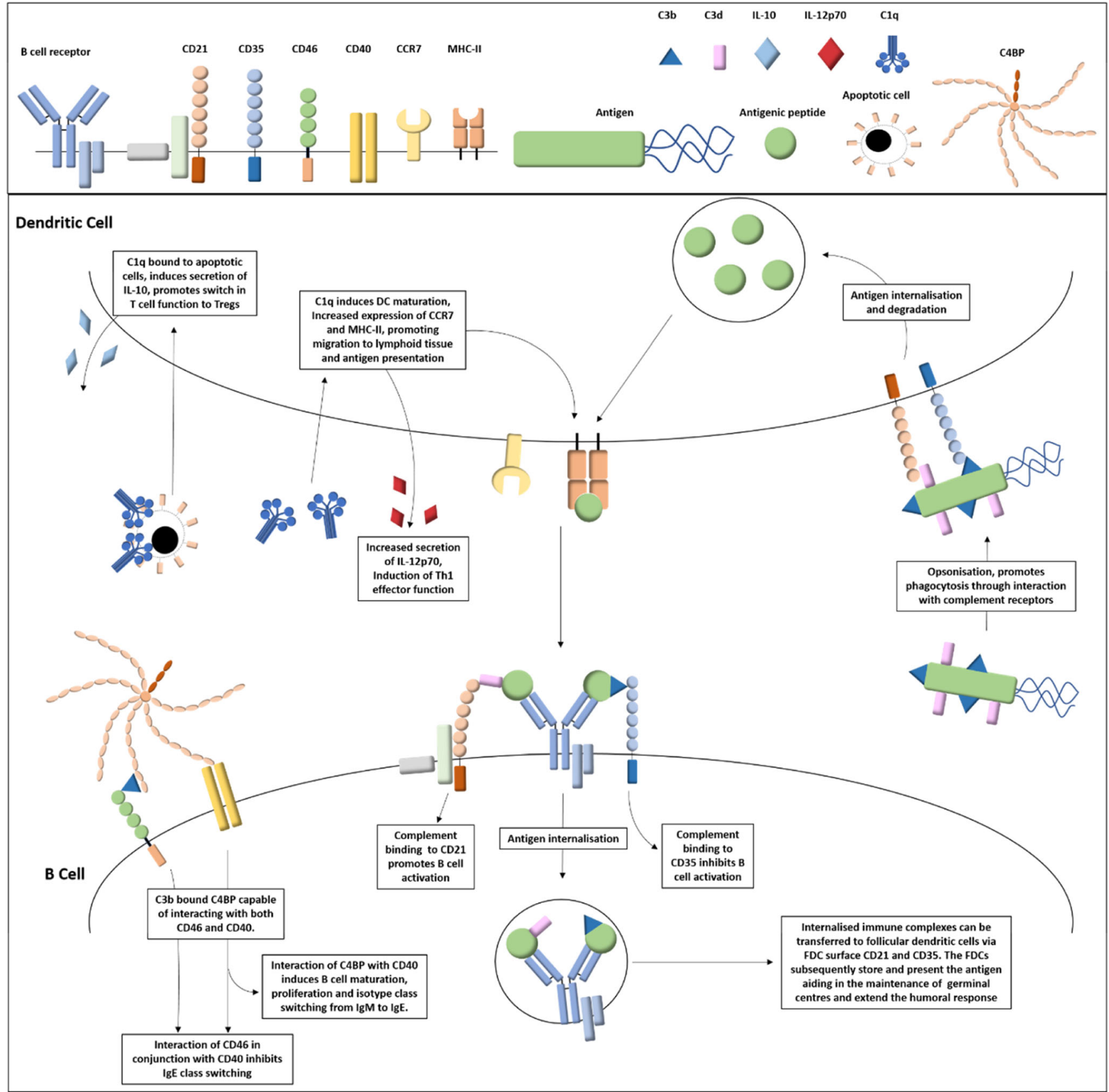

Fig. 1 Complement regulation of dendritic and B cell functions. The interaction of complement component $\mathrm{C} 1 \mathrm{q}$ with dendritic $\mathrm{C} 1 \mathrm{qR}$ results in differential responses dependent on its ligand. Clq bound to microbial surfaces results in DC maturation, increased expression of MHC-II and CCR7, and increased secretion of IL-12p70 resulting in improved ability to present antigen, migration towards the lymphoid tissue and promotion of Th1 effector cell differentiation, respectively. However, C1q bound to apoptotic cells results in secretion of the anti-inflammatory cytokine IL10 as opposed to IL-12p70 resulting in activation of regulatory T cells. $\mathrm{C} 3 \mathrm{~b}$ and $\mathrm{C} 3 \mathrm{~d}$ complement coated antigen is bound by antigen presenting cell surface CD21 and CD35 complement receptors, assisting in antigen

allows $\mathrm{T}$ cell activation but also $\mathrm{T}$ cell termination [54, 55]. Both tails contain a nuclear localization signal (NLS) sequence, and indeed, cleaved tails translocate to the nucleus uptake. The internalized antigen is degraded to antigenic peptide and presented on the surface MHC-II. B cell activation is regulated by complement $\mathrm{C} 3 \mathrm{~d}$ or $\mathrm{C} 3 \mathrm{~b}$ binding to cell surface $\mathrm{CD} 21$ or CD35 resulting in either a reduction in activation threshold or an inhibition of activation, respectively. Complement component $\mathrm{C} 4 \mathrm{BP}$ interacts with a variety of ligands including complement $\mathrm{C} 3 \mathrm{~b}$ and $\mathrm{B}$ cell surface $\mathrm{CD} 40$. Interaction of C4BP with CD40 alone induces B cell activation, proliferation, and antibody class switching from IgM to IgE. However, $\mathrm{C} 3 \mathrm{~b}$ bound $\mathrm{C} 4 \mathrm{BP}$ can bridge interactions between CD46 and CD40 which results in inhibition of CD40 mediated antibody class switching

likely controlling target genes [56]. CD46 expression on activated $\mathrm{T}$ cells is tightly controlled [57-60]. Vitamin $\mathrm{D}$, for example, which is known to promote immune regulation, 
triggers the Th1 to Tr1 switch and favors CD46 cleavage [60]. Expression of CD46 on activated T cells is also under control of a crosstalk with CD28 [61]. Regulation of the splicing of the Cyt1 exon have been recently reported [62]. A few interactors of CD46 tails (albeit only with Cyt1) have been identified, leading to the discovery of the role of CD46 in controlling autophagy (via interaction with GOPC) [63] and cell polarity via binding to DLG4 $[64,65]$. Cyt1 interacts with the kinase SPAK, and this is required for IL-10 production [49]. CD46 also interacts with alpha-E-catenin in human CD4+ T cells and knockdown of $\alpha$-E-catenin impaired CD46 downregulation suggesting a role for $\alpha$-E-catenin in CD46-controlled expression [51]. CD46 is recruited to lipid rafts [66] and T cell polarization is affected by CD46 ligation $[47,65]$. CD46 ligation before specific $\mathrm{T}$ cell activation can prevent subsequent TCR signaling by recruiting the lipid rafts and preventing the immune synapse formation [65], while coligation with the TCR promotes its recruitment to the immune synapse (S. Ni Choileain, J. Hay, et al., submitted). Together, these studies highlight the key role of CD46 signaling on controlling $\mathrm{T}$ cell differentiation and function.

Other members of the RCA family also control $\mathrm{T}$ cell activation. Similar to CD46, CD55 affects co-stimulation of human $\mathrm{T}$ cells by binding to $\mathrm{CD} 97$, promoting $\mathrm{T}$ cell activation and $\operatorname{Tr} 1$ cell differentiation [67]. In mice, it was observed that the lack of CD55 promotes T cell activation, suggesting an inhibitory role of CD55 in T cell effector function $[68,69]$. A role for CD59 in T cell co-stimulation has also been reported [70] and shown to couple signaling events to the TCR [71]. Moreover, recent studies have highlighted an immunomodulatory role of CD59 in T cells suggesting that its ligation may also potentially induce a regulatory $\mathrm{T}$ cell subset [72].

Not only complement regulators but also complement receptors modulate $\mathrm{T}$ cell function and survival. In mice, C5aR and $\mathrm{C} 3 \mathrm{aR}$ act as costimulatory signals for $\mathrm{T}$ cells and sustain naive $\mathrm{T}$ cell survival [30]. C3aR is not expressed at the cell surface of naïve $T$ cells but on lysosomes and is transported to the surface upon T cell activation [73]. Defective cytokine secretion by T cells from $\mathrm{C}_{3 \mathrm{arl}^{-/-}}$and $\mathrm{C} 5 \mathrm{arl} \mathrm{I}^{-/-}$mice show that these receptors are also needed for effector function [30]. In addition, these complement receptors control Treg function. nTregs express $\mathrm{C} 3 \mathrm{aR}$ and $\mathrm{C} 5 \mathrm{aR}$, and triggering of these receptors inhibits Treg suppressive function by modulating Foxp3 expression [74]. $C 3 a R^{-/-}$and $C 5 a R^{-/-}$mice have increased levels of Foxp3 + Tregs [75]. Similarly, blocking these receptors with $\mathrm{C} 3 \mathrm{aR}$ and $\mathrm{C} 5 \mathrm{aR}$ antagonists in human $\mathrm{T}$ cells induced suppressive human iTregs [75].

\section{Production of local and intracellular $C 3$ and C5 in T cells}

Until recently, it was thought that soluble complement components were mostly present in the plasma after production mainly by the liver. In recent years, a series of papers have demonstrated the local production of $\mathrm{C} 3$ and $\mathrm{C} 5$ fragments by adaptive immune cells. In mice, T cell-derived C3 activation is due to the formation of $\mathrm{C} 3$ convertase [30]. In contrast, in resting human $\mathrm{T}$ cells, a recent report suggests that there is continuous production of $\mathrm{C} 3$ that is cleaved by cathepsin $\mathrm{L}$ (CTSL), giving rise to $\mathrm{C} 3 \mathrm{a}$ and $\mathrm{C} 3 \mathrm{~b}$ [3]. The resulting $\mathrm{C} 3 \mathrm{a}$ binds to its $\mathrm{C} 3 \mathrm{aR}$ at the surface of lysosomes and participates to $T$ cell survival by regulation of mechanistic target of rapamycin (mTOR) activity [3]. Upon TCR activation, both $\mathrm{C} 3 \mathrm{a}$ and $\mathrm{C} 3 \mathrm{~b}$ are exported to the cell surface within minutes and bind to surface $\mathrm{C} 3 \mathrm{aR}$, also expressed at the surface after activation, and CD46, respectively, leading to $T$ cell activation and Th1 differentiation. Uncontrolled cleavage results in hyperactivation of Th1 responses, such as that observed in a small number of patients with rheumatoid arthritis, and indeed, inhibition of CTSL normalized the response [3].

Interestingly, CTSL has been linked to inflammatory responses and IL-17 production by controlling Th17 differentiation in both humans and mice [76, 77], suggesting a broader role of cathepsins in regulating inflammatory conditions. This also suggests a role of the $\mathrm{C} 3$ and $\mathrm{C} 5$ fragments in modulating Th17 response.

The same group recently reported the intracellular cleavage of $\mathrm{C} 5$ in T cells upon co-stimulation by CD3/CD46 [12]. Binding of cleaved C5a to intracellular C5R1 leads to activation of the NLRP 3 inflammasome in T cells, and IL- $1 \beta$ production has been reported [12]. The NLRP3-IL-1 $\beta$ axis participates in the activation of CD46 in T cells and IFN $\gamma$ production. On the other hand, binding of $\mathrm{C} 5 \mathrm{a}$ to $\mathrm{C} 5 \mathrm{aR} 2$ that is expressed at the cell surface inhibits this pathway [12]. Of note, we have failed to detect any IL- $1 \beta$ secreted upon CD46 costimulation of T cells from either healthy donors or patients with multiple sclerosis (A. Itchers, J. Killick, A. Astier, unpublished data), and the reasons for these discrepancies are unknown and may relate to the sensitivity of the assays used. Further research will allow clarification on the role of this pathway in T cell differentiation.

It is important to note that key differences between men and mice have been reported. Local production of $\mathrm{C} 3$ and $\mathrm{C} 5$ fragments has been demonstrated in mice, although this was thought to be due to increased $\mathrm{C} 3$ expression and extracellular cleavage by the $\mathrm{C} 3$ convertase [78]. Moreover, although CTSL and C3 are present in murine T cells, normal Th1 differentiation occurred in T cells from CTSL knockout mice, suggesting that $\mathrm{C} 3$ fragments do not require CTSL processing in murine T cells, as opposed to human cells [3]. Moreover, mice do not express CD46 (except for testis), implying that the interaction between $\mathrm{C} 3 \mathrm{~b}$ and $\mathrm{CD} 46$ is not required to generate a Th1 response. It would be interesting to assess the role of the $\mathrm{C} 3 \mathrm{~b}$ receptor and complement regulator Crry in this response, especially as Crry has been also shown to act as a costimulatory molecule for murine $T$ cells [79], similarly to CD46 engagement on human $\mathrm{T}$ cells [46]. 
Importantly, although the role of intracellular complement activation has so far been only shown in human CD4 T cells, intracellular complement activation has been observed in several cell types by the authors, suggesting that this is a general biologic process necessary to overall cell function [3], and the term "complosome" has recently been suggested [80].

\section{Role of complement in $\mathrm{T}$ cell metabolism}

Resting T cells typically have low energy requirements needed to maintain homeostatic functioning. As such, they require only a limited influx of nutrients and have low glycolytic activity, instead deriving energy through mitochondrial oxidative phosphorylation. Upon activation, the energy requirements of the cells rise to support the increased energy demands of cellular proliferation and effector functions [81, 82]. To meet this demand, the activated cells enhance generation of ATP through both glycolysis and oxidative phosphorylation pathways. This process of metabolic adaption to meet the increased energy demands is referred to as metabolic reprogramming. Upon activation, T cells upregulate surface expression of the glucose channel GLUT1 [83] and the amino acid channel LAT1 [84] resulting in increased influx of nutrients. This increased nutrient uptake, particularly the augmented influx of amino acids through the LAT1 channel, is sensed by mTOR $[85,86]$. This subsequently enhances the expression of the transcription factors myc and HIF $1 \alpha$, resulting in increased expression of the glycolytic machinery required for metabolic reprogramming and effector function [85, 87]. While a limitation of glucose availability severely impacts $\mathrm{T}$ cell activation and effector function $[84,87,88]$, T cells display improved effector function with increased glucose [88].

As discussed earlier, upon TCR activation intracellular stores of $\mathrm{C} 3 \mathrm{a}$ and $\mathrm{C} 3 \mathrm{~b}$ are translocated to the cell surface where they interact with cell surface $\mathrm{C} 3 \mathrm{aR}$ and $\mathrm{CD} 46$, respectively $[30,49]$. The interaction between C3b and CD46 modulates the metabolic reprogramming dependent on the CD46 cytoplasmic tails [56]. CD46-Cyt1 isoform when bound by $\mathrm{C} 3 \mathrm{~b}$ signal an increase in cell surface expression of the glucose channel, GLUT1 and the amino acid channel, LAT1, by modulation of miR-150 expression [89]. Moreover, an increase in the expression of MAPK and the MTOR activator 5 (LAMTOR5), which resulted in increased mTOR assembly and glycolysis, was observed. In contrast, activation of the CD46-Cyt2 isoform resulted in a decrease in the rate of glycolysis towards levels observed prior to activation, resulting in Th1 contraction and increased secretion of IL-10. Hence, CD46, depending on its cytoplasmic domain, may lead to increased metabolic state supporting proliferation and effector function of activated $\mathrm{T}$ cells before mediating a switch to a lower glycolytic profile encouraging Th1 contraction and generation of suppressive IL-10 secreting T cells. The key role of CD46 in T cell activation is summarized in Fig. 2. Of note, enzymatic processing of the tails is required to control $\mathrm{T}$ cell activation and cytokine production. While cleavage of Cyt 1 is required to promote IL-10 production, cleavage of Cyt2 was shown to decrease IFN $\gamma$ production and reduce overall $\mathrm{T}$ cell function [54, 55]. Hence, it is clear that the balanced expression of the tails profoundly governs $\mathrm{T}$ cell function, and a deeper understanding of the mechanisms regulating their expression and function is needed.

\section{Aberrant complement regulation in human diseases}

The importance of complement in controlling immune homeostasis is highlighted by the dysregulation of these pathways in a large number of diseases. Analysis of the circulating complement products may also act as biomarkers, as for example increased levels of complement components offer a differential diagnosis between MS and the relatively close neuromyelitis optica spectrum disorder [90]. As discussed earlier, CD46 is key in regulating T cell function. The CD46 pathway has been shown to be dysfunctional in a number of chronic inflammatory diseases. An impaired production of IL10 upon CD46 co-stimulation was observed in patients with relapsing-remitting multiple sclerosis (MS). This was specific to CD46 costimulation as levels of IL-10 were normal when T cells were activated by $\mathrm{CD} 28$, indicating a specific defect in the CD46 pathway [57, 91, 92]. As mice do not express CD46 on somatic cells, the role of CD46 has been studied using an MS model in monkeys that express CD46 on every cell type in a similar fashion to man (although unlike humans, non-human primates also express CD46 on red blood cells), and a similar dysfunction of the regulatory function of CD46 on T cells was observed [93]. The lack of regulatory Th1-Tr1 switch was also reported in rheumatoid arthritis [49] as well as asthma patients $[94,95]$. Hence, chronic inflammation switches CD46 towards an inflammatory response. This was also observed for DCs in MS as CD46-activated DCs produce increased levels of pro-inflammatory IL-23 and chemokines compared to healthy DCs [29]. The exact molecular mechanisms responsible for this inflammatory switch during inflammation are not totally understood and warrant further research. T cell activation leads to a change in glycosylation of CD46 that is required for correct signaling and processing. This regulatory mechanism appears to be altered in T cells from patients with MS, leading to a dysfunctional pathway (S. Ni Choileain, J. Hay, et al., submitted). Importantly, the key role of CD46 in controlling $\mathrm{T}$ cell differentiation is supported by the analysis of CD46-deficient patients. These patients exhibit reduced Th1 cell-mediated responses along with recurrent infections [51]. Similarly, studies using T cells from C3-deficient patients have highlighted the importance of $\mathrm{C} 3$ in Th1 responses. These patients exhibit impaired secretion of IFN $\gamma$ and IL-10. Blockage of $\mathrm{C} 3 \mathrm{aR}$ in healthy $\mathrm{CD} 4+\mathrm{T}$ cells also resulted in diminished IFN $\gamma$ secretion and IL-10 switching [73]. In both 


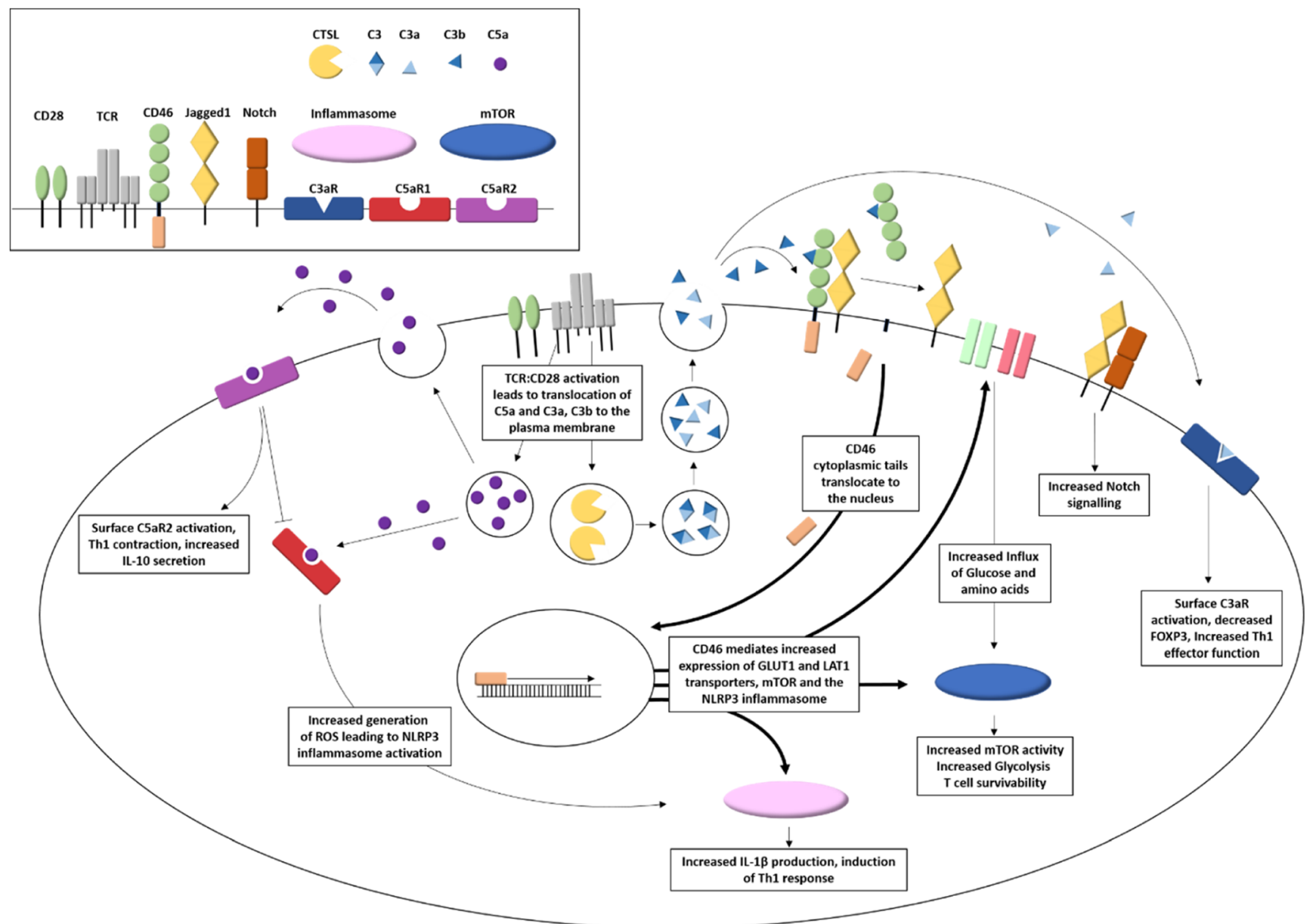

Fig. 2 T cell activation induces autocrine and intracellular complement activation that regulates $\mathrm{T}$ cell metabolic function and inflammasome formation. T cell activation by TCR/CD28 results in the intracellular generation of $\mathrm{C} 5 \mathrm{a}$ and the cathepsin L-mediated cleavage of intracellular $\mathrm{C} 3$ to $\mathrm{C} 3 \mathrm{a}$ and $\mathrm{C} 3 \mathrm{~b}$. Intracellular $\mathrm{C} 5 \mathrm{a}$ activates cytosolic $\mathrm{C} 5 \mathrm{aR} 1$, in addition to being translocated to the plasma membrane allowing interaction with the cell surface C5aR2. Activation of C5aR1 leads to an increase in intracellular ROS generation, which in turn results in the formation of the NLRP3 inflammasome complex. Activation of $\mathrm{C} 5 \mathrm{aR} 2$ by cell secreted $\mathrm{C} 5$ a negatively regulates this process. Lysosomes containing the $\mathrm{C} 3$ cleavage products $\mathrm{C} 3 \mathrm{a}$ and $\mathrm{C} 3 \mathrm{~b}$ are shuttled to the cell membrane leading to $\mathrm{C} 3 \mathrm{a}$ and $\mathrm{C} 3 \mathrm{~b}$ mediated autocrine activation of $\mathrm{C} 3 \mathrm{aR}$ and CD46, respectively. Activation of cell surface $\mathrm{C} 3 \mathrm{aR}$ results in decreased expression of the regulatory $\mathrm{T}$ cell transcription factor FOXP3 and increased Th1 effector functions and IFN $\gamma$ secretion. Cell surface CD46 forms a complex the Notch signaling activator Jagged1. Upon interaction of $\mathrm{C} 3 \mathrm{~b}$ to $\mathrm{CD} 46, \mathrm{CD} 46$ extracellular region is cleaved by metalloproteases and its intracellular cytoplasmic domains further cleaved by a presenilin-gamma secretase complex. Cleavage releases Jagged 1 resulting in activation of the Notch signaling pathway. Translocation of the CD46 cytoplasmic tail to the nucleus results in increased expression of GLUT1 and LAT1 nutrient transporters, mTOR, and the NLRP3 inflammasome

[99]. C1q deficiency leads to accumulation of apoptotic cells and "blebs" containing large quantities of nuclear antigen such as dsDNA which may lead to an auto-immune response [98].

\section{Targeting CD46 as therapy}

The analysis of the in vivo function of CD46 has been largely impaired by the lack of expression of CD46 on somatic cells in mice. Non-human primates are the only animals expressing CD46 in a similar fashion as humans. There have been a few models of CD46-transgenic mice established, and we are developing a model of CD46-expressing zebrafish that will allow the tracking of CD46-expressing T cells upon inflammation and 
provide a potential model to screen drugs affecting this pathway (G. Morisse, D. Sieger, A. Astier, unpublished data). Targeting of the complement regulatory function of CD46 with mutant proteins derived from adenovirus $\mathrm{Ad} 35$ that bind to CD46 with very high affinity enhances response to Rituximab, an antiCD20 antibody in lymphomas in non-human primates [100]. Moreover, this mutant protein was also able to modulate the CD46 pathway in T cells, suggesting that it may be used to modulate other diseases, independently of its complement regulatory function [101]. These data underline that targeting of complement pathways may be a valid approach for future therapies.

\section{Conclusion and perspectives}

Complement components and their interactions with their cognate receptors are therefore key in the control of adaptive immune responses. The most studied cells so far have been $\mathrm{T}$ cells, and as discussed above, complement regulates $\mathrm{T}$ cell activation, differentiation, and metabolism. This offers the perspective of using complement components as novel drug targets for chronic inflammatory diseases and autoimmune diseases. Intracellular activation of complement is now suggested not only in immune cells but also in other cells. Intriguingly, this suggests a much broader role of complement in general cell functions. There is no doubt that research in the coming years will reveal unexpected roles for complement in this regard and highlight how this ancient evolutionary system plays a much more preponderant role in the control of basic cellular mechanisms than initially thought.

Acknowledgements These studies were partly supported by research grants to ALA and DS from the Multiple Sclerosis Society (GB).

Open Access This article is distributed under the terms of the Creative Commons Attribution 4.0 International License (http:// creativecommons.org/licenses/by/4.0/), which permits unrestricted use, distribution, and reproduction in any medium, provided you give appropriate credit to the original author(s) and the source, provide a link to the Creative Commons license, and indicate if changes were made.

\section{References}

1. Walport MJ (2001) Complement. First of two parts. N Engl J Med 344(14):1058-1066. doi:10.1056/NEJM200104053441406

2. Liszewski MK, Elvington M, Kulkarni HS, Atkinson JP (2017) Complement s hidden arsenal: new insights and novel functions inside the cell. Mol Immunol 84:2-9. doi:10.1016/j.molimm. 2017.01.004

3. Liszewski MK, Kolev M, Le Friec G, Leung M, Bertram PG, Fara AF, Subias M, Pickering MC, Drouet C, Meri S, Arstila TP, Pekkarinen PT, Ma M, Cope A, Reinheckel T, Rodriguez de Cordoba S, Afzali B, Atkinson JP, Kemper C (2013) Intracellular complement activation sustains $\mathrm{T}$ cell homeostasis and mediates effector differentiation. Immunity 39(6): 11431157. doi:10.1016/j.immuni.2013.10.018

4. Carroll MC, Isenman DE (2012) Regulation of humoral immunity by complement. Immunity 37(2):199-207. doi:10.1016/j.immuni. 2012.08.002

5. Sharpe AH (2009) Mechanisms of costimulation. Immunol Rev 229(1):5-11. doi:10.1111/j.1600-065X.2009.00784.x

6. Wang C, Collins M, Kuchroo VK (2015) Effector T cell differentiation: are master regulators of effector T cells still the masters? Curr Opin Immunol 37:6-10. doi:10.1016/j.coi.2015.08.001

7. Wing K, Sakaguchi S (2010) Regulatory T cells exert checks and balances on self tolerance and autoimmunity. Nat Immunol 11(1): 7-13. doi:10.1038/ni.1818

8. Rosser EC, Mauri C (2015) Regulatory B cells: origin, phenotype, and function. Immunity 42(4):607-612. doi:10.1016/j.immuni. 2015.04.005

9. Kwan WH, van der Touw W, Heeger PS (2012) Complement regulation of T cell immunity. Immunol Res 54(1-3):247-253. doi:10.1007/s12026-012-8327-1

10. Monk PN, Scola AM, Madala P, Fairlie DP (2007) Function, structure and therapeutic potential of complement C5a receptors. Br J Pharmacol 152(4):429-448. doi:10.1038/sj.bjp.0707332

11. Reis ES, Chen H, Sfyroera G, Monk PN, Kohl J, Ricklin D, Lambris JD (2012) C5a receptor-dependent cell activation by physiological concentrations of desarginated C5a: insights from a novel label-free cellular assay. J Immunol 189(10):4797-4805. doi:10.4049/jimmunol.1200834

12. Arbore G, West EE, Spolski R, Robertson AA, Klos A, Rheinheimer C, Dutow P, Woodruff TM, Yu ZX, O Neill LA, Coll RC, Sher A, Leonard WJ, Kohl J, Monk P, Cooper MA, Arno M, Afzali B, Lachmann HJ, Cope AP, Mayer-Barber KD, Kemper C (2016) T helper 1 immunity requires complementdriven NLRP3 inflammasome activity in CD4(+) T cells. Science 352 (6292):aad1210. doi:10.1126/science.aad1210

13. Li R, Coulthard LG, Wu MC, Taylor SM, Woodruff TM (2013) C5L2: a controversial receptor of complement anaphylatoxin, C5a. FASEB J: Off Publ Fed Am Soc Experiment Biol 27(3): 855-864. doi:10.1096/fj.12-220509

14. Okinaga S, Slattery D, Humbles A, Zsengeller Z, Morteau O, Kinrade MB, Brodbeck RM, Krause JE, Choe HR, Gerard NP, Gerard C (2003) C5L2, a nonsignaling C5A binding protein. Biochemistry 42(31):9406-9415. doi:10.1021/bi034489v

15. Scola AM, Johswich KO, Morgan BP, Klos A, Monk PN (2009) The human complement fragment receptor, C5L2, is a recycling decoy receptor. Mol Immunol 46(6):1149-1162. doi:10.1016/j. molimm.2008.11.001

16. Cattaneo R (2004) Four viruses, two bacteria, and one receptor: membrane cofactor protein (CD46) as pathogens magnet. J Virol 78(9):4385-4388

17. Meri S, Morgan BP, Davies A, Daniels RH, Olavesen MG, Waldmann H, Lachmann PJ (1990) Human protectin (CD59), an 18,000-20,000 MW complement lysis restricting factor, inhibits C5b-8 catalysed insertion of C9 into lipid bilayers. Immunology 71(1):1-9

18. Ross GD, Lambris JD, Cain JA, Newman SL (1982) Generation of three different fragments of bound $\mathrm{C} 3$ with purified factor I or serum. I. Requirements for factor $\mathrm{H}$ vs CR1 cofactor activity. J Immunol 129(5):2051-2060

19. Webb JH, Blom AM, Dahlback B (2002) Vitamin K-dependent protein $\mathrm{S}$ localizing complement regulator $\mathrm{C} 4 \mathrm{~b}$-binding protein to the surface of apoptotic cells. J Immunol 169(5):2580-2586

20. Trouw LA, Bengtsson AA, Gelderman KA, Dahlback B, Sturfelt G, Blom AM (2007) C4b-binding protein and factor $\mathrm{H}$ compensate for the loss of membrane-bound complement inhibitors to protect apoptotic cells against excessive complement attack. J Biol Chem 282(39):28540-28548. doi:10.1074/jbc.M704354200 
21. Harrison RA, Lachmann PJ (1980) The physiological breakdown of the third component of human complement. Mol Immunol 17(1):9-20

22. Suzuki K, Grigorova I, Phan TG, Kelly LM, Cyster JG (2009) Visualizing B cell capture of cognate antigen from follicular dendritic cells. J Exp Med 206(7):1485-1493. doi:10.1084/jem.20090209

23. Castellano G, Woltman AM, Nauta AJ, Roos A, Trouw LA, Seelen MA, Schena FP, Daha MR, van Kooten C (2004) Maturation of dendritic cells abrogates $\mathrm{C} 1 \mathrm{q}$ production in vivo and in vitro. Blood 103(10):3813-3820. doi:10.1182/blood2003-09-3046

24. Csomor E, Bajtay Z, Sandor N, Kristof K, Arlaud GJ, Thiel S, Erdei A (2007) Complement protein C1q induces maturation of human dendritic cells. Mol Immunol 44(13):3389-3397. doi:10. 1016/j.molimm.2007.02.014

25. Clarke EV, Weist BM, Walsh CM, Tenner AJ (2015) Complement protein $\mathrm{C} 1 \mathrm{q}$ bound to apoptotic cells suppresses human macrophage and dendritic cell-mediated Th17 and Th1 T cell subset proliferation. J Leukoc Biol 97(1):147-160. doi:10.1189/jlb. 3A0614-278R

26. Kandasamy M, Ying PC, Ho AW, Sumatoh HR, Schlitzer A, Hughes TR, Kemeny DM, Morgan BP, Ginhoux F, Sivasankar B (2013) Complement mediated signaling on pulmonary CD103(+) dendritic cells is critical for their migratory function in response to influenza infection. PLoS Pathog 9(1):e1003115. doi:10.1371/journal.ppat.1003115

27. Karp CL (1999) Measles: immunosuppression, interleukin-12, and complement receptors. Immunol Rev 168:91-101

28. Kurita-Taniguchi M, Fukui A, Hazeki K, Hirano A, Tsuji S, Matsumoto M, Watanabe M, Ueda S, Seya T (2000) Functional modulation of human macrophages through CD46 (measles virus receptor): production of IL-12 p40 and nitric oxide in association with recruitment of protein-tyrosine phosphatase SHP-1 to CD46. J Immunol 165(9):5143-5152

29. Vaknin-Dembinsky A, Murugaiyan G, Hafler DA, Astier AL, Weiner HL (2008) Increased IL-23 secretion and altered chemokine production by dendritic cells upon CD46 activation in patients with multiple sclerosis. J Neuroimmunol 195(1-2):140-145

30. Strainic MG, Liu J, Huang D, An F, Lalli PN, Muqim N, Shapiro VS, Dubyak GR, Heeger PS, Medof ME (2008) Locally produced complement fragments $\mathrm{C} 5 \mathrm{a}$ and $\mathrm{C} 3 \mathrm{a}$ provide both costimulatory and survival signals to naive CD4+ T cells. Immunity 28(3):425435. doi:10.1016/j.immuni.2008.02.001

31. Olivar R, Luque A, Cardenas-Brito S, Naranjo-Gomez M, Blom AM, Borras FE, Rodriguez de Cordoba S, Zipfel PF, Aran JM (2016) The complement inhibitor factor $\mathrm{H}$ generates an antiinflammatory and Tolerogenic state in monocyte-derived dendritic cells. J Immunol 196(10):4274-4290. doi:10.4049/jimmunol. 1500455

32. Dixon KO, O'Flynn J, Klar-Mohamad N, Daha MR, van Kooten C (2017) Properdin and factor $H$ production by human dendritic cells modulates their T-cell stimulatory capacity and is regulated by IFN-gamma. Eur J Immunol 47(3):470-480. doi:10.1002/eji. 201646703

33. DeFranco AL (1996) The two-headed antigen. B-cell co-receptors. Curr Biol: CB 6(5):548-550

34. Calderhead DM, Kosaka Y, Manning EM, Noelle RJ (2000) CD40-CD154 interactions in B-cell signaling. Curr Top Microbiol Immunol 245(2):73-99

35. Dempsey PW, Allison ME, Akkaraju S, Goodnow CC, Fearon DT (1996) C3d of complement as a molecular adjuvant: bridging innate and acquired immunity. Science 271(5247):348-350

36. Masaki T, Matsumoto M, Nakanishi I, Yasuda R, Seya T (1992) Factor I-dependent inactivation of human complement $\mathrm{C} 4 \mathrm{~b}$ of the classical pathway by $\mathrm{C} 3 \mathrm{~b} / \mathrm{C} 4 \mathrm{~b}$ receptor $(\mathrm{CR} 1, \mathrm{CD} 35)$ and membrane cofactor protein (MCP, CD46). J Biochem 111(5):573-578
37. Jozsi M, Prechl J, Bajtay Z, Erdei A (2002) Complement receptor type 1 (CD35) mediates inhibitory signals in human B lymphocytes. J Immunol 168(6):2782-2788

38. Cherukuri A, Cheng PC, Pierce SK (2001) The role of the CD19/CD21 complex in B cell processing and presentation of complement-tagged antigens. J Immunol 167(1):163-172

39. Lanzavecchia A (1990) Receptor-mediated antigen uptake and its effect on antigen presentation to class II-restricted T lymphocytes. Annu Rev Immunol 8:773-793. doi:10.1146/annurev.iy.08. 040190.004013

40. Brimnes MK, Hansen BE, Nielsen LK, Dziegiel MH, Nielsen CH (2014) Uptake and presentation of myelin basic protein by normal human B cells. PLoS One 9(11):e113388. doi:10.1371/journal. pone. 0113388

41. Heesters BA, Chatterjee P, Kim YA, Gonzalez SF, Kuligowski MP, Kirchhausen T, Carroll MC (2013) Endocytosis and recycling of immune complexes by follicular dendritic cells enhances B cell antigen binding and activation. Immunity 38(6):1164-1175. doi: 10.1016/j.immuni.2013.02.023

42. Aubry JP, Pochon S, Graber P, Jansen KU, Bonnefoy JY (1992) $\mathrm{CD} 21$ is a ligand for CD23 and regulates IgE production. Nature 358(6386):505-507. doi:10.1038/358505a0

43. Henchoz-Lecoanet S, Jeannin P, Aubry JP, Graber P, Bradshaw CG, Pochon S, Bonnefoy JY (1996) The Epstein-Barr virus-binding site on CD21 is involved in CD23 binding and interleukin-4induced $\operatorname{IgE}$ and $\mathrm{IgG} 4$ production by human B cells. Immunology 88(1):35-39

44. Brodeur SR, Angelini F, Bacharier LB, Blom AM, Mizoguchi E, Fujiwara H, Plebani A, Notarangelo LD, Dahlback B, Tsitsikov E, Geha RS (2003) C4b-binding protein (C4BP) activates B cells through the CD40 receptor. Immunity 18(6):837-848

45. Imani F, Proud D, Griffin DE (1999) Measles virus infection synergizes with IL-4 in IgE class switching. J Immunol 162(3): 1597-1602

46. Astier A, Trescol-Biemont MC, Azocar O, Lamouille B, Rabourdin-Combe C (2000) Cutting edge: CD46, a new costimulatory molecule for $\mathrm{T}$ cells, that induces $\mathrm{p} 120 \mathrm{CBL}$ and LAT phosphorylation. J Immunol 164(12):6091-6095

47. Zaffran Y, Destaing O, Roux A, Ory S, Nheu T, Jurdic P, Rabourdin-Combe C, Astier AL (2001) CD46/CD3 costimulation induces morphological changes of human $\mathrm{T}$ cells and activation of Vav, Rac, and extracellular signalregulated kinase mitogen-activated protein kinase. J Immunol 167(12):6780-6785

48. Hawkins ED, Oliaro J (2010) CD46 signaling in T cells: linking pathogens with polarity. FEBS Lett 584(24):4838-4844. doi:10. 1016/j.febslet.2010.09.003

49. Cardone J, Le Friec G, Vantourout P, Roberts A, Fuchs A, Jackson I, Suddason T, Lord G, Atkinson JP, Cope A, Hayday A, Kemper C (2010) Complement regulator CD46 temporally regulates cytokine production by conventional and unconventional T cells. Nat Immunol 11(9):862-871. doi:10.1038/ni.1917

50. Kemper C, Chan AC, Green JM, Brett KA, Murphy KM, Atkinson JP (2003) Activation of human CD4(+) cells with CD3 and CD46 induces a T-regulatory cell 1 phenotype. Nature 421(6921):388-392

51. Le Friec G, Sheppard D, Whiteman P, Karsten CM, Shamoun SA, Laing A, Bugeon L, Dallman MJ, Melchionna T, Chillakuri C, Smith RA, Drouet C, Couzi L, Fremeaux-Bacchi V, Kohl J, Waddington SN, McDonnell JM, Baker A, Handford PA, Lea SM, Kemper C (2012) The CD46-Jagged1 interaction is critical for human TH1 immunity. Nat Immunol 13(12):1213-1221. doi: 10.1038/ni.2454

52. Rutz S, Janke M, Kassner N, Hohnstein T, Krueger M, Scheffold A (2008) Notch regulates IL-10 production by T helper 1 cells. 
Proc Natl Acad Sci U S A 105(9):3497-3502. doi:10.1073/pnas. 0712102105

53. Marie JC, Astier AL, Rivailler P, Rabourdin-Combe C, Wild TF, Horvat B (2002) Linking innate and acquired immunity: divergent role of CD46 cytoplasmic domains in T cell induced inflammation. Nat Immunol 3(7):659-666

54. Ni Choileain S, Astier AL (2012) CD46 processing: a means of expression. Immunobiology 217(2):169-175. doi:10.1016/j. imbio.2011.06.003

55. Ni Choileain S, Weyand NJ, Neumann C, Thomas J, So M, Astier AL (2011) The dynamic processing of CD46 intracellular domains provides a molecular rheostat for T cell activation. PLoS One 6(1): e16287. doi:10.1371/journal.pone.0016287

56. Kolev M, Dimeloe S, Le Friec G, Navarini A, Arbore G, Povoleri GA, Fischer M, Belle R, Loeliger J, Develioglu L, Bantug GR, Watson J, Couzi L, Afzali B, Lavender P, Hess C, Kemper C (2015) Complement regulates nutrient influx and metabolic reprogramming during Th1 cell responses. Immunity 42(6): 1033-1047. doi:10.1016/j.immuni.2015.05.024

57. Astier AL, Meiffren G, Freeman S, Hafler DA (2006) Alterations in CD46-mediated $\operatorname{Tr} 1$ regulatory T cells in patients with multiple sclerosis. J Clin Invest 116(12):3252-3257

58. Hansen AS, Bundgaard BB, Moller BK, Hollsberg P (2016) Nonrandom pairing of $\mathrm{CD} 46$ isoforms with skewing towards $\mathrm{BC} 2$ and C2 in activated and memory/effector T cells. Sci Rep 6:35406. doi: 10.1038/srep35406

59. Kickler K, Maltby K, Ni Choileain S, Stephen J, Wright S, Hafler DA, Jabbour HN, Astier AL (2012) Prostaglandin E2 affects T cell responses through modulation of CD46 expression. J Immunol 188(11):5303-5310. doi:10.4049/jimmunol.1103090

60. Kickler K, Ni Choileain S, Williams A, Richards A, Astier AL (2012) Calcitriol modulates the CD46 pathway in T cells. PLoS One 7(10):e48486. doi:10.1371/journal.pone.0048486

61. Charron L, Doctrinal A, Ni Choileain S, Astier AL (2015) Monocyte:T-cell interaction regulates human T-cell activation through a CD28/CD46 crosstalk. Immunol Cell Biol 93(9):796803. doi:10.1038/icb.2015.42

62. Tang SJ, Luo S, Ho JX, Ly PT, Goh E, Roca X (2016) Characterization of the regulation of CD46 RNA alternative splicing. J Biol Chem 291(27):14311-14323. doi:10.1074/jbc.M115. 710350

63. Meiffren G, Joubert PE, Gregoire IP, Codogno P, RabourdinCombe C, Faure M (2010) Pathogen recognition by the cell surface receptor CD46 induces autophagy. Autophagy 6(2)

64. Ludford-Menting MJ, Thomas SJ, Crimeen B, Harris LJ, Loveland BE, Bills M, Ellis S, Russell SM (2002) A functional interaction between CD46 and DLG4: a role for DLG4 in epithelial polarization. J Biol Chem 277(6):4477-4484

65. Oliaro J, Pasam A, Waterhouse NJ, Browne KA, LudfordMenting MJ, Trapani JA, Russell SM (2006) Ligation of the cell surface receptor, CD46, alters T cell polarity and response to antigen presentation. Proc Natl Acad Sci U S A 103(49):1868518690. doi:10.1073/pnas.0602458103

66. Ludford-Menting MJ, Crimeen-Irwin B, Oliaro J, Pasam A, Williamson D, Pedersen N, Guillaumot P, Christansen D, Manie S, Gaus K, Russell SM (2011) The reorientation of T-cell polarity and inhibition of immunological synapse formation by CD46 involves its recruitment to lipid rafts. J Lipids 2011:521863. doi:10. $1155 / 2011 / 521863$

67. Sutavani RV, Bradley RG, Ramage JM, Jackson AM, Durrant LG, Spendlove I (2013) CD55 costimulation induces differentiation of a discrete T regulatory type 1 cell population with a stable phenotype. J Immunol 191(12):5895-5903. doi:10.4049/jimmunol. 1301458

68. Heeger PS, Lalli PN, Lin F, Valujskikh A, Liu J, Muqim N, Xu Y, Medof ME (2005) Decay-accelerating factor modulates induction of T cell immunity. J Exp Med 201(10):1523-1530. doi:10.1084/ jem.20041967

69. Liu J, Miwa T, Hilliard B, Chen Y, Lambris JD, Wells AD, Song WC (2005) The complement inhibitory protein DAF (CD55) suppresses T cell immunity in vivo. J Exp Med 201(4):567-577. doi: 10.1084/jem.20040863

70. Korty PE, Brando C, Shevach EM (1991) CD59 functions as a signal-transducing molecule for human $\mathrm{T}$ cell activation. $\mathrm{J}$ Immunol 146(12):4092-4098

71. Deckert M, Ticchioni M, Mari B, Mary D, Bernard A (1995) The glycosylphosphatidylinositol-anchored CD59 protein stimulates both $\mathrm{T}$ cell receptor zeta/ZAP-70-dependent and -independent signaling pathways in T cells. Eur J Immunol 25(7):1815-1822. doi: 10.1002/eji.1830250704

72. Sivasankar B, Longhi MP, Gallagher KM, Betts GJ, Morgan BP, Godkin AJ, Gallimore AM (2009) CD59 blockade enhances antigen-specific CD4+ $\mathrm{T}$ cell responses in humans: a new target for cancer immunotherapy? J Immunol 182(9):5203-5207. doi: 10.4049/jimmunol.0804243

73. Ghannam A, Pernollet M, Fauquert JL, Monnier N, Ponard D, Villiers MB, Peguet-Navarro J, Tridon A, Lunardi J, Gerlier D, Drouet C (2008) Human C3 deficiency associated with impairments in dendritic cell differentiation, memory B cells, and regulatory T cells. J Immunol 181(7):5158-5166

74. Kwan WH, van der Touw W, Paz-Artal E, Li MO, Heeger PS (2013) Signaling through C5a receptor and C3a receptor diminishes function of murine natural regulatory T cells. J Exp Med 210(2):257-268. doi:10.1084/jem.20121525

75. Strainic MG, Shevach EM, An F, Lin F, Medof ME (2013) Absence of signaling into CD4(+) cells via C3aR and C5aR enables autoinductive TGF-betal signaling and induction of Foxp3(+) regulatory T cells. Nat Immunol 14(2):162-171. doi: 10.1038/ni.2499

76. Tuomela S, Salo V, Tripathi SK, Chen Z, Laurila K, Gupta B, Aijo T, Oikari L, Stockinger B, Lahdesmaki H, Lahesmaa R (2012) Identification of early gene expression changes during human Th17 cell differentiation. Blood 119(23):e151-e160. doi:10. 1182/blood-2012-01-407528

77. Hou L, Cooley J, Swanson R, Ong PC, Pike RN, Bogyo M, Olson ST, Remold-O'Donnell E (2015) The protease cathepsin L regulates Th17 cell differentiation. J Autoimmun 65:56-63. doi:10. 1016/j.jaut.2015.08.006

78. Lalli PN, Strainic MG, Yang M, Lin F, Medof ME, Heeger PS (2008) Locally produced C5a binds to T cell-expressed C5aR to enhance effector T-cell expansion by limiting antigen-induced apoptosis. Blood 112(5):1759-1766. doi:10.1182/blood-2008-04151068

79. Fernandez-Centeno E, de Ojeda G, Rojo JM, Portoles P (2000) Crry/p65, a membrane complement regulatory protein, has costimulatory properties on mouse T cells. J Immunol 164(9): 4533-4542

80. Hess C, Kemper C (2016) Complement-mediated regulation of metabolism and basic cellular processes. Immunity 45(2):240 254. doi:10.1016/j.immuni.2016.08.003

81. Frauwirth KA, Riley JL, Harris MH, Parry RV, Rathmell JC, Plas DR, Elstrom RL, June CH, Thompson CB (2002) The CD28 signaling pathway regulates glucose metabolism. Immunity 16(6):769-777

82. Chang CH, Curtis JD, Maggi LB Jr, Faubert B, Villarino AV, O'Sullivan D, Huang SC, van der Windt GJ, Blagih J, Qiu J, Weber JD, Pearce EJ, Jones RG, Pearce EL (2013) Posttranscriptional control of $\mathrm{T}$ cell effector function by aerobic glycolysis. Cell 153(6):1239-1251. doi:10.1016/j.cell.2013.05.016

83. Macintyre AN, Gerriets VA, Nichols AG, Michalek RD, Rudolph MC, Deoliveira D, Anderson SM, Abel ED, Chen BJ, Hale LP, Rathmell JC (2014) The glucose transporter Glut1 is selectively 
essential for CD4 T cell activation and effector function. Cell Metab 20(1):61-72. doi:10.1016/j.cmet.2014.05.004

84. Sinclair LV, Rolf J, Emslie E, Shi YB, Taylor PM, Cantrell DA (2013) Control of amino-acid transport by antigen receptors coordinates the metabolic reprogramming essential for $\mathrm{T}$ cell differentiation. Nat Immunol 14(5):500-508. doi:10.1038/ni.2556

85. Finlay DK, Rosenzweig E, Sinclair LV, Feijoo-Carnero C, Hukelmann JL, Rolf J, Panteleyev AA, Okkenhaug K, Cantrell DA (2012) PDK1 regulation of mTOR and hypoxia-inducible factor 1 integrate metabolism and migration of CD8+ T cells. $\mathrm{J}$ Exp Med 209(13):2441-2453. doi:10.1084/jem.20112607

86. Angela M, Endo Y, Asou HK, Yamamoto T, Tumes DJ, Tokuyama H, Yokote K, Nakayama T (2016) Fatty acid metabolic reprogramming via mTOR-mediated inductions of PPARgamma directs early activation of T cells. Nat Commun 7:13683. doi:10. 1038/ncomms 13683

87. Wang R, Dillon CP, Shi LZ, Milasta S, Carter R, Finkelstein D, McCormick LL, Fitzgerald P, Chi H, Munger J, Green DR (2011) The transcription factor Myc controls metabolic reprogramming upon T lymphocyte activation. Immunity 35(6):871-882. doi:10. 1016/j.immuni.2011.09.021

88. Jacobs SR, Herman CE, Maciver NJ, Wofford JA, Wieman HL, Hammen JJ, Rathmell JC (2008) Glucose uptake is limiting in T cell activation and requires CD28-mediated Akt-dependent and independent pathways. J Immunol 180(7):4476-4486

89. King BC, Esguerra JL, Golec E, Eliasson L, Kemper C, Blom AM (2016) CD46 activation regulates miR-150-mediated control of GLUT1 expression and cytokine secretion in human CD4+ T cells. J Immunol 196(4):1636-1645. doi:10.4049/jimmunol. 1500516

90. Hakobyan S, Luppe S, Evans DR, Harding K, Loveless S, Robertson NP, Morgan BP (2016) Plasma complement biomarkers distinguish multiple sclerosis and neuromyelitis optica spectrum disorder. Mult Scler:1352458516669002. doi:10.1177/ 1352458516669002

91. Astier AL, Hafler DA (2007) Abnormal Tr1 differentiation in multiple sclerosis. J Neuroimmunol 191(1-2):70-78

92. Chiarini M, Serana F, Zanotti C, Capra R, Rasia S, Rottoli M, Rovaris M, Caputo D, Cavaletti G, Frigo M, Frigeni B, Clerici R, Rezzonico M, Caimi L, Imberti L (2011) Modulation of the central memory and Tr1-like regulatory T cells in multiple sclerosis patients responsive to interferon-beta therapy. Mult Scler. doi: $10.1177 / 1352458511427720$

93. Ma A, Xiong Z, Hu Y, Qi S, Song L, Dun H, Zhang L, Lou D, Yang P, Zhao Z, Wang X, Zhang D, Daloze P, Chen H (2009) Dysfunction of IL-10-producing type 1 regulatory $\mathrm{T}$ cells and CD4+CD25+ regulatory T cells in a mimic model of human multiple sclerosis in Cynomolgus monkeys. Int Immunopharmacol 9(5):599-608

94. Tsai YG, Niu DM, Yang KD, Hung CH, Yeh YJ, Lee CY, Lin CY (2012) Functional defects of CD46-induced regulatory T cells to suppress airway inflammation in mite allergic asthma. Lab Investig 92(9):1260-1269. doi:10.1038/labinvest.2012.86

95. Xu YQ, Gao YD, Yang J, Guo W (2010) A defect of CD4+CD25+ regulatory $\mathrm{T}$ cells in inducing interleukin-10 production from CD4+ T cells under CD46 costimulation in asthma patients. $\mathrm{J}$ Asthma 47(4):367-373. doi:10.3109/02770903.2010.481340

96. Kremlitzka M, Polgar A, Fulop L, Kiss E, Poor G, Erdei A (2013) Complement receptor type 1 (CR1, CD35) is a potent inhibitor of B-cell functions in rheumatoid arthritis patients. Int Immunol 25(1):25-33. doi:10.1093/intimm/dxs090

97. Scott D, Botto M (2015) The paradoxical roles of $\mathrm{C} 1 \mathrm{q}$ and $\mathrm{C} 3$ in autoimmunity. Immunobiology 221(6):719-725. doi:10.1016/j. imbio.2015.05.001

98. Walport MJ, Davies KA, Botto M (1998) C1q and systemic lupus erythematosus. Immunobiology 199(2):265-285. doi:10.1016/ s0171-2985(98)80032-6

99. Korb LC, Ahearn JM (1997) C1q binds directly and specifically to surface blebs of apoptotic human keratinocytes: complement deficiency and systemic lupus erythematosus revisited. J Immunol 158(10):4525-4528

100. Richter M, Yumul R, Saydaminova K, Wang H, Gough M, Baldessari A, Cattaneo R, Lee F, Wang CH, Jang H, Astier A, Gopal A, Carter D, Lieber A (2016) Preclinical safety, pharmacokinetics, pharmacodynamics, and biodistribution studies with Ad35K++ protein: a novel rituximab cotherapeutic. Mol Ther Methods Clin Dev 5:16013. doi:10.1038/mtm.2016.13

101. Hay J, Carter D, Lieber A, Astier AL (2015) Recombinant Ad35 adenoviral proteins as potent modulators of human T cell activation. Immunology 144(3):453-460. doi:10.1111/imm. 12391 